\title{
Chemical Defenses of the Endemic Brazilian Gorgonian Lophogorgia violacea Pallas (Octocorallia, Gorgonacea)
}

\author{
Rosângela de A. Epifanio ${ }^{a}{ }^{*}$, Lenize F. Maia ${ }^{b}$ and William Fenical ${ }^{c}$ \\ ${ }^{a}$ Departamento de Química Orgânica, Instituto de Química, Universidade Federal Fluminense, \\ Campus do Valonguinho, 24020-150, Niterói - RJ, Brazil \\ ${ }^{b}$ Núcleo de Pesquisas de Produtos Naturais, Universidade Federal do Rio de Janeiro, 21941-590, \\ Rio de Janeiro - RJ, Brazil \\ ${ }^{c}$ Center for Marine Biotechnology and Biomedicine, Scripps Institution of Oceanography, \\ University of California, San Diego, La Jolla, CA, USA 92093-0204
}

\begin{abstract}
O mecanismo de defesa contra predadores no octocoral brasileiro Lophogorgia violacea foi investigado através de ensaios de preferência alimentar em campo frente a predadores. Os ensaios de palatabilidade com o extrato bruto da gorgônia demonstraram que seus metabólitos secundários possuem atividade deterrente significativa frente a peixes generalistas. $\mathrm{O}$ fracionamento do extrato bruto, guiado pelos ensaios em campo, revelou que uma mistura complexa de furanocembranolídeos é a responsável pela defesa química de $L$. violacea. O diterpeno lophotoxina (1) foi a principal

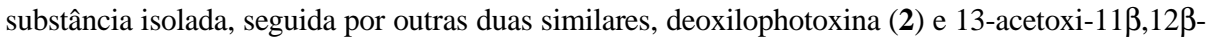
epoxipukalídeo (3), além de dois furanocembranolídeos inéditos na literatura, 7-acetoxi-8hidroxilophotoxina (4) e 3-metoxi-8-hidroxilophotoxina (5). A lophotoxina (1), uma importante neurotoxina, originalmente isolada de $L$. rigida do Pacífico, demonstrou ser a mais potente dentre as substâncias fagoinibidoras presentes no extrato bruto. Por outro lado, os outros quatro furanocembranolídeos isolados também parecem contribuir, de maneira aditiva, para a atividade total observada. Estes resultados corroboram estudos prévios, confirmando que furanocembranolídeos são uma classe de substâncias de defesa frente ao consumo por peixes em ambientes tropicais e temperados.
\end{abstract}

The chemical defenses of the Brazilian gorgonian octocoral Lophogorgia violacea Pallas have been investigated using feeding preference experiments performed in situ with an ecologically relevant, natural assemblage of predatory fishes. Feeding experiments incorporating the crude extract of the animal into palatable foods showed that the organic constituents of $L$. violacea provide a powerful chemical deterrence toward consumption by generalist fish carnivores. Bioassayguided fractionation of the extract and evaluation of the fractions and purified compounds obtained in the same in situ assay revealed that a complex mixture of furanocembranolides was responsible for the overall feeding deterrence observed. The most potent feeding deterrent identified was lophotoxin (1), followed by two previously reported and structurally related compounds, deoxylophotoxin (2), and 13-acetoxy-11 $\beta, 12 \beta$-epoxypukalide (3), as well as two new furanocembranolides: 7-acetoxy-8-hydroxylophotoxin (4) and 3-methoxy-8-hydroxylophotoxin (5). Lophotoxin (1), a neurotoxin originally isolated from the Pacific gorgonian $L$. rigida, was the most potent feeding deterrent among the furanocembranolides isolated. However, the four other related furanocembranolides (2-5) appear to contribute, in an additive manner, to the overall deterrent effects observed. These results add to earlier studies providing further evidence that compounds of this structural class provide effective chemical defenses against fish predators in both temperate and tropical environments.

Keywords: Cnidaria, Lophogorgia violacea, furanocembranolides, marine chemical ecology, feeding deterrents

*e-mail: rosangela@ rmn.uff.br 


\section{Introduction}

Gorgonian octocorals (Gorgonaceae, Octocorallia) are a unique group of marine cnidarians, which thrive in tropical to warm temperate oceans, being most abundant and diverse in shallow Caribbean waters. Diverse from the stony corals, they do not have an external calcium carbonate skeleton, but calcitic sclerites embedded in their coenenchyme that are thought to serve as structural support for the colony ${ }^{1,2}$. Despite their relative abundance in coral reefs, habitats characterized by high levels of predation and nutrient scarcity, octocorals seem to be free of predation with the exception of some specialist consumers (e.g. polychaetes, mollusks, and butterflyfishes) ${ }^{1}$. Explanations for the low predation rates on gorgonians may include both physical and chemical defenses but only very recently have relevant laboratory or field experiments been employed to test these hypotheses ${ }^{3}$.

Sclerites from Pseudopterogorgia acerosa have been demonstrated to deter predation in field assays ${ }^{2}$. This study indicated the important role that structural elements can play in the defense against some potential consumers in gorgonians corals, or why some gorgonian specialists fishes (e.g. chaetodontids) consume only the polyps and not the coenenchyme ${ }^{2}$.

Chemical defense, however, has been the primary explanation for the relative lack of predation in gorgonian corals. Such experiments have identified a large number of crude octocoral extracts that are avoided by co-occurring fishes. These studies involved at least 28 species (Anthonellidae, Briareidae, Gorgonidae, Nephteidae, Plexauridae and Alcyonidae) of Caribbean ${ }^{2,4-10}$, Pacific $^{11,12}$, western North Atlantic ${ }^{13}$ and, recently, Brazilian species ${ }^{14,15}$. Although the results obtained revealed a high incidence of crude extracts causing fish avoidance, to date only ten different natural pure compounds, including sesquiterpenes, diterpenes and acetogenins, isolated from eight chemically defended octocoral species, have proven to be authentic feeding deterrents $2,7-10,12-15$.

The extensive Brazilian coastline is rich in marine organisms, but assessments of ecological roles of their natural products have been rare and restricted to only a few studies ${ }^{14-21}$. Recently, investigation of the chemical defenses in two Brazilian gorgonians revealed that different compounds, like the Caribbean species studied, are responsible for their chemical defense. Although several compounds have been isolated from Phyllogorgia dilatata $^{21}$ only the diterpene $11 \beta, 12 \beta$-epoxypukalide showed deterrent activity in field assays ${ }^{14}$. Likewise, investigation of the Brazilian gorgonian Heterogorgia uatumani demonstrated that defenses were derived from the additive effects of an eunicellane diterpenoid and a sesquiterpene lactone, heterogorgiolide, isolated from the bioactive crude extract ${ }^{15}$.

As part of our continuing interest in the natural products chemistry and chemical ecology of Brazilian marine invertebrates ${ }^{14-16,21-25}$, we have investigated the chemistry and feeding deterrence properties of Lophogorgia violacea Pallas, an endemic species occurring in the southeast regions of Brazil $^{26}$. In this report, we describe the isolation and identification of the secondary metabolites (Figure 1) responsible for the observed deterrence.

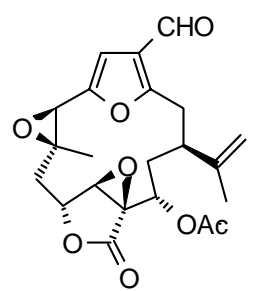

1

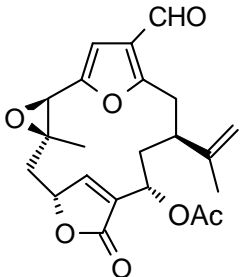

2

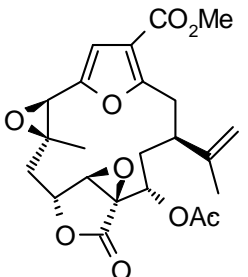

3

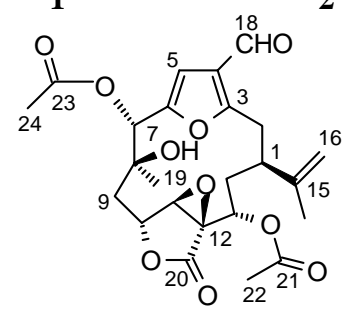

4

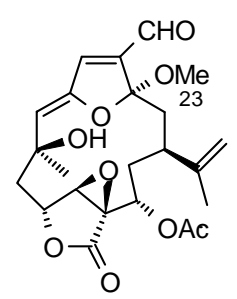

5
Figure 1. Furanocembranolides from Lophogorgia violacea.

\section{Experimental}

\section{General procedures}

Normal phase HPLC was carried out on a semipreparative silica gel column (Dynamax column) using a Waters model 510 pump and a model 401 differential refractometer detector. NMR spectra were recorded in $\mathrm{CDCl}_{3}$ solution on Varian Unity $500 \mathrm{MHz}$, Bruker 200 and $300 \mathrm{MHz}$ spectrometers. IR spectra were recorded on a Perkin-Elmer model 1600 (FTIR) spectrometer. Mass measurements were obtained using a HP 5989A mass spectrometer. UV spectra were obtained on a Shimadzu model 1601 spectrophotometer. Optical rotation of compound 4 was measured on a Perkin-Elmer 243B $\left(D_{25}\right.$ $=589 \mathrm{~nm}, c=1.0, \mathrm{CHCl}_{3}$ ), while that of 5 was measured on a JASCO DIP-370 $\left(\mathrm{D}_{25}=589 \mathrm{~nm}, c=1.0, \mathrm{CHCl}_{3}\right)$. Corrected melting points were determined on a Thomas-Hoover capillary melting point apparatus.

\section{Octocoral collection}

Colonies of Lophogorgia violacea Pallas 1766, a species endemic to southeast Brazil ${ }^{17}$, were collected 
using SCUBA at 10-12 meters depth at Arraial do Cabo, Rio de Janeiro state, Brazil on March, 1994. The specimens were frozen immediately after collection.

\section{Extracts, fractions and pure compounds}

Freeze dried Lophogorgia violacea (758 g, corresponding to $810 \mathrm{~cm}^{3}$ of fresh gorgonian) was cut into small pieces and extracted at room temperature with 3:7 methanol:dichloromethane (once) and pure dichloromethane (twice) solvent mixtures. Organic extracts were combined and evaporated under reduced pressure affording $18 \mathrm{~g}$ of a brownish gum. The crude extract was fractionated by silica gel (300 mesh) vacuum flash chromatography, employing a gradient ranging from 10 to $100 \%$ of ethyl acetate in isooctane, to yield five fractions (Fractions A-E). All of them were analyzed by silica gel thin layer chromatography and by ${ }^{1} \mathrm{H}$ NMR spectrometry. Part of fractions $\mathrm{B}$ and $\mathrm{C}$ was further purified by normal phase HPLC (EtOAc:isooctane 1:1), to yield pure lophotoxin (1, $162.6 \mathrm{mg}, 0.09 \%$ dry weight), deoxylophotoxin $(2,32.1 \mathrm{mg}, 0.03 \%$ dry weight $)$, 13 -acetoxy-11 $\beta, 12 \beta$-epoxypukalide $(\mathbf{3}, 9.4 \mathrm{mg}, 0.01 \%$ dry weight) and 7-acetoxy,8-hydroxylophotoxin $(4,11.2 \mathrm{mg}$, $0.005 \%$ dry weight). Purification of part of fraction D by normal phase HPLC (4:6 hexane:ethyl acetate) furnished compound 5 ( $28.4 \mathrm{mg}, 0.02 \%$ dry weight).

Lophotoxin (1) ${ }^{27}:{ }^{1} \mathrm{H}$ NMR (200 MHz, $\left.\mathrm{CDCl}_{3}\right) \delta 1.14$ (s, H-19), 1.73 (m, H-14a), 1.90 (s, H-17), 2.05 (s, H-22), 2.08 (m, H-9a), 2.49 (m, H-9b), 2.49 (m, H-14b), 2.90 (dd, $J$ 17.0 and $12.0 \mathrm{~Hz}, \mathrm{H}-2 \mathrm{a}$ ), 3.07 (dd, $J 17.0$ and $4.0 \mathrm{~Hz}, \mathrm{H}-$ 2b), 3.90 (dt, $J 12.0$ and $4.0 \mathrm{~Hz}, \mathrm{H}-11$ ), 4.09 (d, $J 1.0 \mathrm{~Hz}, \mathrm{H}-$ 7), 4.18 (s, H-11), 4.81 (dd, J 4.4 and $2.8 \mathrm{~Hz}, \mathrm{H}-10$ ), 4.91 (m, H-16a), 4.93 (br s, H-16b), 4.98 (d, J7.2 Hz, H-13), 6.57 (d, $J 1.0 \mathrm{~Hz}, \mathrm{H}-5), 9.87$ (s, H-18); ${ }^{13} \mathrm{C} \mathrm{NMR}(50 \mathrm{MHz}$, $\left.\mathrm{CDCl}_{3}\right) \delta 20.2$ (C-19), 20.4 (C-22), 21.1 (C-17), 31.6 (C14), 32.9 (C-2), 36.3 (C-1), 39.0 (C-9), 55.2 (C-7), 55.9 (C8), 61.1 (C-12), 64.0 (C-11), 70.2 (C-13), 76.4 (C-10), 123.0 (C-4), 105.6 (C-5), 111.0 (C-16), 148.1 (C-15), 149.7 (C6), 161.7 (C-3), 170.2 (C-20), 184.3 (C-18); LREIMS (70 eV) $m / z \quad 416\left(\mathrm{M}^{+}, 16\right), 374$ (3), 356 (22), 341 (3), 313 (3), 137 (83), 83 (100).

Deoxylophotoxin $(2)^{28}:{ }^{1} \mathrm{H} \mathrm{NMR}\left(500 \mathrm{MHz}, \mathrm{CDCl}_{3}\right)$ $\delta 0.95$ (s, H-19), 1.23 (d, J 15.0 Hz, H-14a), 1.88 (s, H-17), 1.99 (s, H-22), 2.18 (dd, $J 15.0$ and $3.0 \mathrm{~Hz}, \mathrm{H}-9 \mathrm{a}), 2.53$ (m, H-9b), 2.55 (m, H-14b), 2.97 (m, H-2), 4.04 (dt, J 10.0 and 6.5 Hz, H-1), 4.09 (s, H-7), 4.89 (s, H-16a), 5.00 (s, H-16b), 5.24 (br s, H-10b), 5.83 (d, J 6.5 Hz, H-13), 6.42 (s, H-5), 7.30 (s, H-11), 9.84 (s, H-18); ${ }^{13} \mathrm{C} \mathrm{NMR}\left(50 \mathrm{MHz}, \mathrm{CDCl}_{3}\right)$

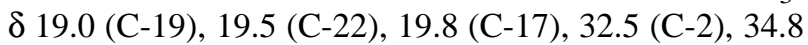
(C-14), 36.0 (C-1), 39.3 (C-9), 54.3 (C-7), 56.0 (C-8), 68.0
(C-13), 77.0 (C-10), 104.0 (C-5), 111.0 (C-16), 123.0 (C-4), 134.0 (C-12), 148.0 (C-15), 149.0 (C-6), 151.0 (C-11), 163.0 (C-3), 170.5 (C-20), 170.5 (C-21), 184.0 (C-18).

Compound $3{ }^{29}:{ }^{1} \mathrm{H}$ NMR $\left(500 \mathrm{MHz}, \mathrm{CDCl}_{3}\right) \delta 0.99(\mathrm{~s}$, H-19), 1.30 (m, H-14a), 1.89 (s, H-17), 2.00 (s, H-22), 2.20 (m, H-9a), 2.50 (m, H-14b), 2.90 (m, H-2a), 3.00 (m, H-2b), 3.80 (s, H-23), 3.90 (m, H-1), 4.09 (s, H-7), 4.88 (br s, H16b), 4.99 (br s, H-16b), 5.25 (br s, H-10), 5.80 (d, J 8.0 Hz, $\mathrm{H}-13), 6.40$ (s, H-5), 7.28 (s, H-11); ${ }^{13} \mathrm{C} \mathrm{NMR} \mathrm{(50} \mathrm{MHz,}$ $\mathrm{CDCl}_{3}$ ) $\delta 19.6$ (C-19), 20.5 (C-22), 20.7 (C-17), 34.2 (C-2), 35.8 (C-14), 36.7 (C-1), 39.8 (C-9), 51.3 (C-23), 54.9 (C7), 68.7 (C-13), 56.7 (C-8), 76.3 (C-10), 106.8 (C-5), 110.9 (C-16), 114.0 (C-4), 135.0 (C-12), 148.1 (C-15), 148.9 (C6), 150.9 (C-11) 160.0(C-3), 164.2 (C-18); LREIMS (70eV) $\mathrm{m} / \mathrm{z} 430\left(\mathrm{M}^{+}, 13\right), 398(7), 370$ (38), 338 (38), 165 (65), 84 (100).

Compound 4: white crystals from 1:1 hexane:ethyl acetate, m.p. $254-258{ }^{\circ} \mathrm{C}$; $[\alpha]^{25}{ }_{\mathrm{D}}-13^{\circ}\left(c\right.$ 1.0, $\left.\mathrm{CHCl}_{3}\right)$; IR $v_{\max } / \mathrm{cm}^{-1} 3460,1780,1730,1670\left(\right.$ film); ${ }^{1} \mathrm{H}$ and ${ }^{13} \mathrm{C}$ NMR see Table 1; LREIMS (70eV) m/z $476\left(\mathbf{M}^{+}, 3\right), 434$ (11), 416 (18), 374 (3), 356 (5), 338 (5), 279 (12), 237 (27), 180 (43), 138 (100); HRFABMS $\left(\mathrm{MNH}_{4}^{+}\right)$: Found $\mathrm{m} / \mathrm{z}$ 494.204000; Calc. for $\mathrm{C}_{24} \mathrm{H}_{32} \mathrm{O}_{10} \mathrm{~N}, 494.202622$.

Compound 5: white amorphous solid, m.p. $172-175^{\circ} \mathrm{C}$; $[\alpha]^{25}{ }_{\mathrm{D}}-190^{\circ}$ (c 1.0, $\mathrm{CHCl}_{3}$ ); IR $v_{\max } / \mathrm{cm}^{-1} 3450,1770$, 1720, 1670 (film); UV $\lambda_{\text {max }} / \mathrm{nm}(\mathrm{MeOH}) 320 \mathrm{~nm}(\varepsilon 1.5 \mathrm{x}$ $\left.10^{-3}\right) ;{ }^{1} \mathrm{H}$ and ${ }^{13} \mathrm{C}$ NMR see Table 1 ; LREIMS $(70 \mathrm{eV}) \mathrm{m} / \mathrm{z}$ $448\left(\mathrm{M}^{+}, 11\right), 430$ (16), 419 (31), 401 (20), 341 (33), 256 (19), 182 (90), 165 (100), 149 (64), 121 (81), 95 (83), 79 (75); HRFABMS $\left(\mathrm{MNH}_{4}^{+}\right)$: Found $\mathrm{m} / z$ 466.209900; Calc. for $\mathrm{C}_{23} \mathrm{H}_{32} \mathrm{O}_{9} \mathrm{~N}, 466.207707$.

\section{Palatability assay}

Food strips were prepared using the established methodology $7,8,14,16$, which involved homogenizing 2.5 g carrageenan (Sigma C-1013 type 1), $20 \mathrm{~cm}^{3}$ commercial tunafish puree (packed in oil) in $60 \mathrm{~cm}^{3}$ of water. In separate experiments, crude gorgonian extract and fractions were volumetrically reconstituted in a matrix of the carrageenanbased food at the same concentration as they occurred in the gorgonian fresh tissues (final volume of $60 \mathrm{~cm}^{3}$ ). Compound 1 was assayed in two different concentrations $\left(0.9\right.$ and $\left.1.5 \mathrm{mg} \mathrm{cm}^{-3}\right)$. For each experiment, 20 treated and 20 control strips $(1.0 \times 0.6 \times 5.0 \mathrm{~cm}$ each $)$ were arranged in pairs and attached to 20 ropes. The ropes were anchored slightly above the bottom near to the same site the L. violacea colonies were collected. Within $3 \mathrm{hr}$ the ropes were retrieved and the amount of each strip eaten was measured. During the experiments, several common tropical fishes, well known to occur in the studied area, 


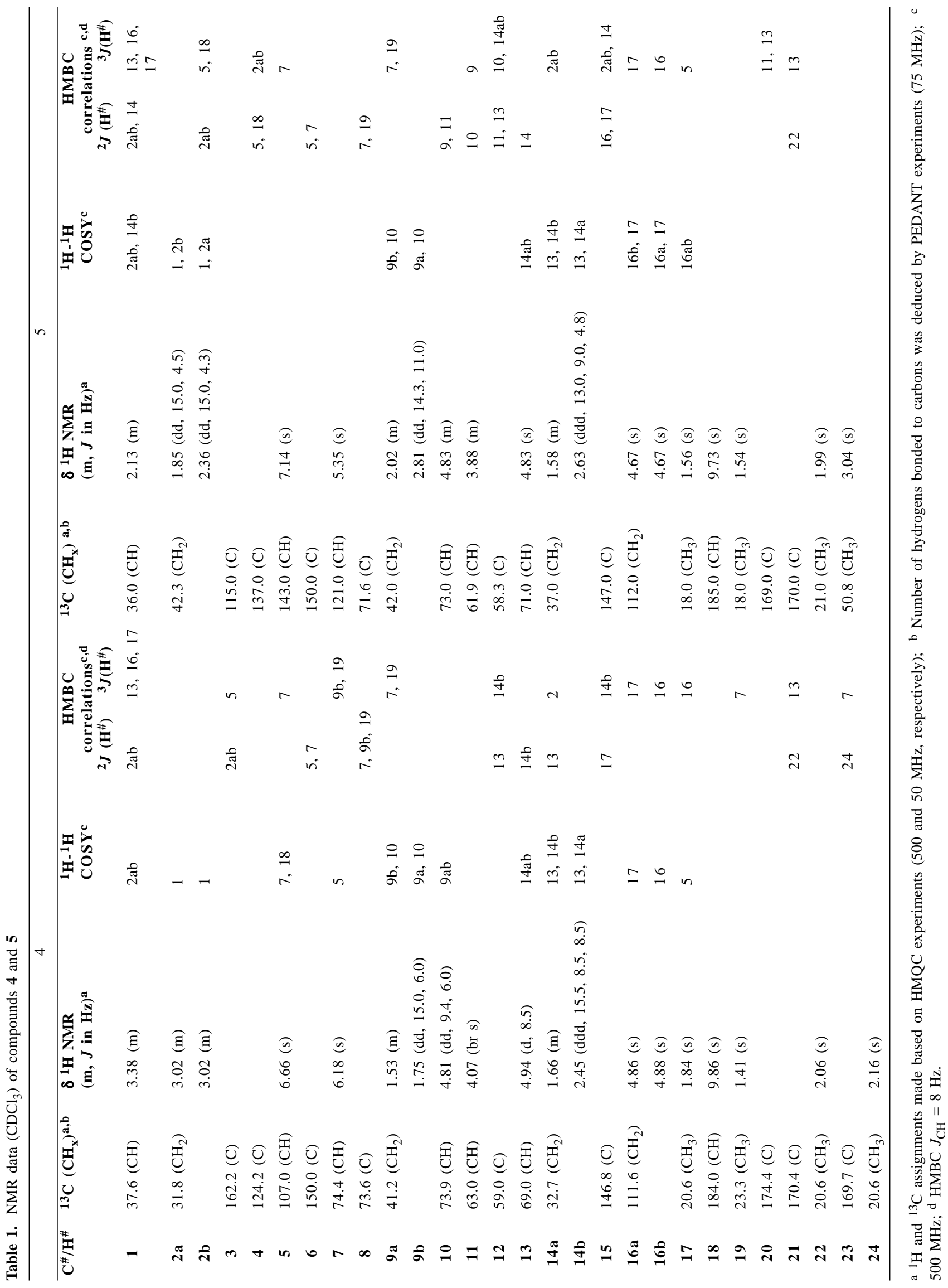


were observed feeding on the test strips. These included, but were not limited to Halichoeris poeyi (Labridae), Diplodus argentus (Sparidae), Monochantus sp. (Balistidae), and Sphoeroides testudineus (Tetraodontidae $)^{30}$. Field assays and underwater observations were performed using a portable surface air supply diving apparatus. The Wilcoxon paired-sample test was used to analyze the results (one-tail) ${ }^{31}$.

\section{Results and Discussion}

\section{Isolation and structure elucidation of diterpenes}

Specimens of the gorgonian $L$. violacea collected at Arraial do Cabo, RJ, were immediately frozen and freeze dried prior the extraction with dichloromethane and methanol. The combined extracts were fractionated by vacuum flash chromatography on silica gel to yield five fractions. Proton-NMR analysis revelead that fractions B and $\mathrm{C}$ were rich in furanocembranolides by the characteristic deshielded signals between $\delta_{\mathrm{H}} 9.0$ to 10.0 and 4.0 to 7.0. Subsequent purification of fraction B by normal phase HPLC, using 1:1 isooctane:ethyl acetate, afforded compounds 1, 2 and $\mathbf{3}$. Purification of fraction $\mathrm{C}$ by normal phase HPLC using the same solvent system also yielded compounds $\mathbf{1}$ and $\mathbf{2}$, along with the diterpene 4. Compound 5 was obtained by HPLC purification of fraction D (normal phase, 4:6 hexane:ethyl acetate).

The spectral data obtained of compounds $\mathbf{1 - 3}$ were in agreement with those reported in literature for lophotoxin, deoxylophotoxin and 13-acetoxy-11 $\beta, 12 \beta$-epoxypukalide, respectively $27-29,32$.

The structures and relative stereochemistries of the new diterpenes $\mathbf{4}$ and $\mathbf{5}$ were established by 1D and 2D NMR experiments, including ${ }^{1} \mathrm{H}-{ }^{1} \mathrm{H}-\mathrm{COSY},{ }^{1} \mathrm{H}-{ }^{1} \mathrm{H}-\mathrm{NOESY}$, $\mathrm{HMQC}$ and $\mathrm{HMBC}$. The ${ }^{1} \mathrm{H}$ and ${ }^{13} \mathrm{C}$ NMR chemical shifts assignments are shown in Table 1 for the cembranolides 4 and $\mathbf{5}$, which are described here for the first time.

Compound 4 was isolated as white crystals from hexane:ethyl acetate (m.p. $254-258{ }^{\circ} \mathrm{C},[\alpha]_{D}{ }^{25}-13^{\circ}$ (c 1.0, $\mathrm{CDCl}_{3}$ )) with molecular formula $\mathrm{C}_{24} \mathrm{H}_{28} \mathrm{O}_{10}$ by HRCI mass spectroscopic data $\left(\left[\mathrm{MNH}_{4}\right]^{+} \mathrm{m} / z\right.$ found 494.204000, calc. 494.202622) and combined NMR methods. The IR spectrum of $\mathbf{4}$ revealed absorptions assigned to hydroxyl $\left(3460 \mathrm{~cm}^{-1}\right), \gamma$-lactone $\left(1780 \mathrm{~cm}^{-1}\right)$, ester $\left(1730 \mathrm{~cm}^{-1}\right)$ and aldehyde $\left(1670 \mathrm{~cm}^{-1}\right)$ functionalities. Carbon-13 NMR experiments (HBBD and PEDANT) indicated the presence of four methyl groups, four methylene ( $3 \mathrm{sp}^{3}$ and $\left.1 \mathrm{sp}^{2}\right)$, seven methines $\left(5 \mathrm{sp}^{3}\right.$ and $\left.2 \mathrm{sp}^{2}\right)$ and nine quaternary carbons $\left(2 \mathrm{sp}^{3}\right.$ and $7 \mathrm{sp}^{2}$ ). The HMQC and HMBC experiments established, respectively, the direct correlation $\left({ }^{1} J_{\mathrm{CH}}\right)$ and two or three bond correlations $\left(2,3 J_{\mathrm{CH}}\right)$ between all carbons and hydrogens in the structure (Table 1). The data obtained revealed that $\mathbf{4}$ was a furanocembranolide closely related to lophotoxin (1) with a unique feature: the presence of a 7acetoxyl-8-hydroxyl moiety instead of the 7,8-epoxy group, contained in the majority of the known furanocembranolides. The ${ }^{2,3} J_{\mathrm{CH}}$ cross peaks observed in the HMBC spectrum between the acetyl carbonyl carbon at $\delta_{\mathrm{C}} 169.7(\mathrm{C}-23)$ and the hydrogens of the methyl group at $\delta_{\mathrm{H}} 2.13(\mathrm{~s}, \mathrm{H}-24)$ and the methine at $6.18(\mathrm{~s}, \mathrm{H}-7)$, as well as between the carbon signal at $\delta_{\mathrm{C}} 73.6(\mathrm{C}-8)$ and the hydrogens at $\delta_{\mathrm{H}} 6.18(\mathrm{~s}, \mathrm{H}-7)$, $1.75(\mathrm{dd}, J=15.0$ and $6.0 \mathrm{~Hz}, \mathrm{H}-9 \mathrm{~b})$ and 1.41 (s, H-19) confirmed the 7-acetoxyl, 8-hydroxyl substitution pattern. The relative stereochemistry of $\mathbf{4}$ was deduced based on the coupling constants between $\mathrm{H}-9 \mathrm{~b}, \mathrm{H}-10$ and $\mathrm{H}-11,{ }^{1} \mathrm{H}-{ }^{1} \mathrm{H}$ NOESY $\left(300 \mathrm{MHz}, \mathrm{CDCl}_{3}\right.$ ) data and comparison with literature observations obtained for related compounds ${ }^{33}$.

Although nuclear Overhauser enhancements recorded for flexible molecules such as $\mathbf{4}$ are often unreliable in the determination of relative stereochemistry, the correlations observed between the signals at $\delta_{\mathrm{H}} 1.41(\mathrm{H}-19), 1.75$ (H-9b), 4.07 (H-11), 4.81 (H-10), 6.18 (H-7) and $6.66(\mathrm{H}-5)$ provided reasonable evidence to support the structure assigned in Figure 1.

Compound 5 was obtained as a white amorphous solid (m.p. $172-175^{\circ} \mathrm{C},[\alpha]_{\mathrm{D}}{ }^{25}-19^{\circ}\left(c 1.0, \mathrm{CDCl}_{3}\right)$ ) after the purification of fraction D. The molecular formula of 5 was assigned as $\mathrm{C}_{23} \mathrm{H}_{28} \mathrm{O}_{9}$ by HRCI mass spectroscopy $\left(\left[\mathrm{MNH}_{4}\right]^{+} \mathrm{m} / \mathrm{z}\right.$ found 466.209900 , calc. 466.207707$)$ and combined NMR experiments. HBBD and PENDANT ${ }^{13} \mathrm{C}$ NMR experiments revealed that 5 contained four methyl groups, four methylene ( $3 \mathrm{sp}^{3}$ and $1 \mathrm{sp}^{2}$ ), seven methine (4 $\mathrm{sp}^{3}$ and $\left.3 \mathrm{sp}^{2}\right)$ and eight quaternary carbon atoms $\left(3 \mathrm{sp}^{3}\right.$ and $5 \mathrm{sp}^{2}$ ). The IR absorption at $3450 \mathrm{~cm}^{-1}$ suggested the presence of a hydroxyl group and the absorption bands at 1770 and $1720 \mathrm{~cm}^{-1}$, coupled with NMR data, confirmed the presence of $\alpha, \beta$-epoxy- $\gamma$-lactone and acetate ester functionalities. The presence of a methoxyl group was indicated by ${ }^{1} \mathrm{H}$ and ${ }^{13} \mathrm{C}$ NMR signals at $\delta_{\mathrm{H}} 3.04(3 \mathrm{H}, \mathrm{s})$ and $\delta_{\mathrm{C}} 50.8\left(\mathrm{CH}_{3}\right)$. The $\alpha, \beta, \gamma, \delta$-unsaturated aldehyde functionality was deduced by an UV absorbance at $320 \mathrm{~nm}(\varepsilon 1,500$, calc. $327 \mathrm{~nm})$, and by HMBC cross peaks observed between the signals at $\delta_{\mathrm{C}} 150.0(\mathrm{C}-6), \delta_{\mathrm{H}} 7.14$ $(\mathrm{H}-5)$ and $5.35(\mathrm{H}-7)$ and between $\delta_{\mathrm{C}} 71.6(\mathrm{C}-8), \delta_{\mathrm{H}} 5.35$ (H-7) and 1.54 (H-19). These data suggested that 5 was a methanol adduct of lophotoxin (1). The position of the methoxyl group in $\mathrm{C}-3$ was confirmed by HMBC correlations between $\delta_{\mathrm{C}} 115.0(\mathrm{C}-3)$ and $\delta_{\mathrm{H}} 3.04(\mathrm{H}-23)$, $9.73(\mathrm{H}-18)$ and $7.14(\mathrm{H}-5)$. The assignment of the hydroxyl carbon bearing at $\mathrm{C}-8$ was also corroborated by $\mathrm{HMBC}$ correlations between $\delta_{\mathrm{C}} 71.6(\mathrm{C}-8)$ with $\delta_{\mathrm{H}} 5.35(\mathrm{H}-7)$ and 
1.54 (H-19). As for the diterpene 4, the relative stereochemistry of 5 was proposed on the basis of ${ }^{1} \mathrm{H}-{ }^{1} \mathrm{H}$ coupling constants, by ${ }^{1} \mathrm{H}_{-}{ }^{1} \mathrm{H}$ NOESY experiments $\left(300 \mathrm{MHz}, \mathrm{CDCl}_{3}\right)$ and comparison with literature data $27,29,33$.

The use of methanol during the extraction procedure might suggest that $\mathbf{5}$ is an artifact product from lophotoxin (1). To test this hypothesis, a solution of lophotoxin in methanol was left at room temperature for 24 hours and then analyzed by TLC and ${ }^{1} \mathrm{H}$ NMR. This experiment revealed that lophotoxin (1) in contact with methanol afforded a complex mixture of more polar compounds, among which 5 was observed by several signals between $\delta_{\mathrm{H}} 3.0$ and 3.5 which appeared in the ${ }^{1} \mathrm{H}$ NMR spectrum. However, crude extracts prepared with $100 \%$ dichloromethane or dichloromethane:methanol $(7: 3)$ had exactly the same appearance in ${ }^{1} \mathrm{H}$ NMR spectra and TLC analyses, leading us to conclude that the extraction method was not responsible for the methanol incorporation in lophotoxin.

Although different Lophogorgia species collected at southwestern coast of California and Mexico yielded furanocembranolides, this is the first report of this class of compounds from a Brazilian species ${ }^{27,28}$. A previous study of Lophogorgia punicea, also collected in the vicinity of Rio de Janeiro, afforded only common 3-hydroxy sterols, hydroquinone and punicin ${ }^{22}$.

\section{Palatability field assays}

Organic crude extract of the Brazilian Gorgoniidae Lophogorgia violacea was unpalatable to a natural assemblage of reef fishes in the field. The extract, when incorporated into a tuna fish flavored carrageenan matrix, significantly inhibited feeding by fishes in comparison with controls (Figure 2, $P<0.0001$ ).

In order to identify the metabolite(s) responsible for the feeding avoidance observed, we fractionated the crude extract and obtained five mixtures of compounds with different polarities (Fractions A-E). Fractions B and C were rich in furanocembranolide diterpenes, a class of natural products comprising over 16 diterpenoids which has been exclusively isolated from octocorals $21,27-29,33-38$. Only three of these compounds have been previously investigated as icthyodeterrents (Figure 2) 11-14. Compounds 6, 7 and 8 (Figure 2) were isolated, respectively, from Guam specimens of Sinularia maxima (Alcyonacea) ${ }^{11}$, Leptogorgia virgulata from North Carolina coast ${ }^{13}$ and the Brazilian endemic gorgonian Phyllogorgia dilatata ${ }^{14,21}$. All of them proved to have icthyodeterrent activity when assayed in aquaria or under natural conditions in the field. The mixture of diterpenes in fractions B and C, when evaluated individually, did not

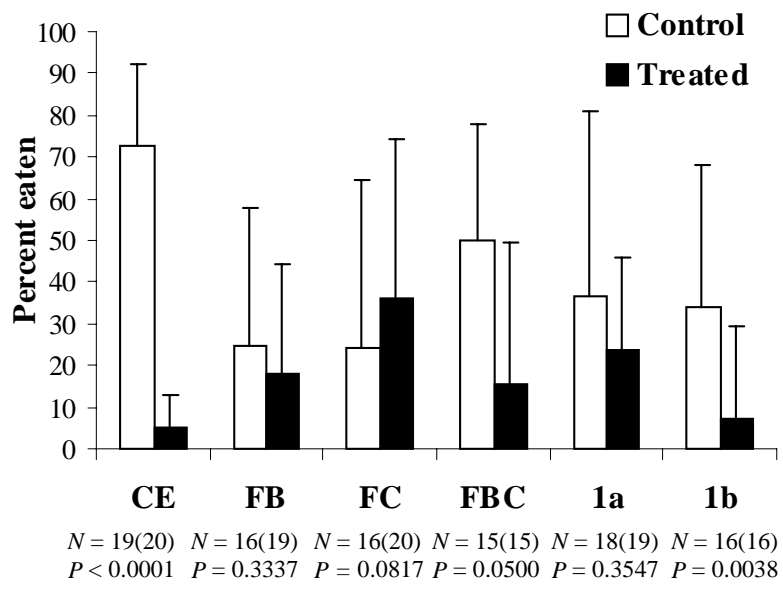

Figure 2. Consumption by co-occurring fishes of paired carrageenan based food-strips with (treated) and without (control) L. violacea crude extracts (CE: $c 22.2 \mathrm{mg} \mathrm{cm}^{-3}$ ), semi-purified fractions (B: $c 2.3 \mathrm{mg} \mathrm{cm}^{-3}$, C: $c 1.2 \mathrm{mg} \mathrm{cm}^{-3}$, BC: $c 3.5 \mathrm{mg} \mathrm{cm}^{-3}$ ), and lophotoxin (1) (1a: $\left.c 0.9 \mathrm{mg} \mathrm{cm}^{-3}, \mathbf{1 b}: c 1.5 \mathrm{mg} \mathrm{cm}^{-3}\right)$. Error bars represent $\mathrm{SD} . N=$ no. of paired treated and control strips used in statistical analysis (parentheses indicated no. of pairs retrieved of 20 deployed). $P=$ probability calculated with the Wilcoxon pairedsample test, one-tailed.

deter predation (Figure 2, $P=0.3337$ and 0.0817 , respectively). However, food pellets containing the mixture of fractions $\mathrm{B}$ and $\mathrm{C}$ showed significant deterrent activity $(P=0.0500)$.

Four furanocembranolides (1-4) were isolated from these fractions, and lophotoxin (1, Figure 1) was the major compound. Due to limitations of the amount of each compound available for field assays, we could only test the activity of lophotoxin (1) under natural conditions.

It was difficult to estimate the natural concentration of $\mathbf{1}$ in L. violacea tissue, mainly because the purification of the diterpenes involved loss of metabolites and the techniques employed may had resulted in metabolite degradation (e.g. the formation of 5). To increase the confidence of the assays, we tested lophotoxin in two different concentrations. In the first experiment $\left(0.9 \mathrm{mg} \mathrm{cm}^{-3}\right)$ we used the amount of pure lophotoxin (1) obtained from the crude extract. The second concentration $\left(1.5 \mathrm{mg} \mathrm{cm}^{-3}\right)$ was an estimative of the natural concentration, taking into account the probability of artifact formation (e.g. 5) and a $20 \%$ loss of lophotoxin during the purification process. Our results showed that lophotoxin was active only when assayed at the higher concentration $(P=0.0038$, Figure 2$)$. Nevertheless, this concentration $\left(1.5 \mathrm{mg} \mathrm{cm}^{-3}\right.$ equal to about $0.7 \%$ dry weight pellet) was less then those used in the assays of $\mathbf{6}$ and 7 . In earlier studies, the diterpene $\mathbf{6}$ was shown to deter feeding of generalist fishes ${ }^{11}$ at a concentration of $2 \%$ dry weight, while 7 induced vomiting in killifish ${ }^{13}$ after incorporation on gelatin pellets at a concentration of $2 \mathrm{mg} \mathrm{cm}^{-3}$. 


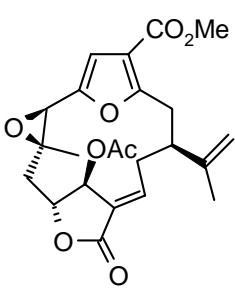

6

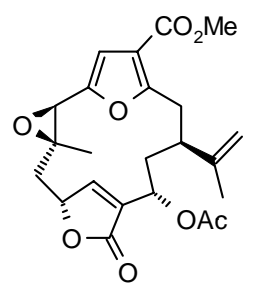

7

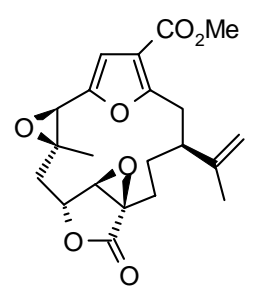

8
Figure 3. Ichtyodeterrent furanocembranolides from Octocorallia.

The fish species observed during our experiments were the same that were observed in the in situ palatability assay using 8, isolated from Phyllogorgia dilatata ${ }^{14}$. The furanocembranolide 8 was deterrent $(P<0.0001)$ at a concentration of $0.31 \mathrm{mg} \mathrm{cm}^{-3}$.

These results led us to conclude that a mixture of diverse furanocembranolide diterpenes, with lophotoxin (1) as the major metabolite, is responsible for the potent feeding deterrent effects observed for the $L$. violacea crude extract. Indeed, it appears common that the overall effects of deterrence are derived not by a single compound, but by complex mixtures of metabolites, whose additive effects provide amazingly effective defenses against predators ${ }^{15}$.

Furanocembranolides have been previously isolated from several species of the orders Alcyonacea (Sinularia abrupta, S. polydactyla, S. dissecta and Gersemia rubiformis) and Gorgonacea (Lophogorgia alba, L. cuspidata, L. rigida, L. chilensis, Leptogorgia setacea, Pseudopterogorgia acerosa and Phyllogorgia dilatata) 21,27-29,33-38. To date, compounds 2, 4 and 5 have only been found in Lophogorgia species. Compounds $\mathbf{1}$ and $\mathbf{3}$ are common to several Lophogorgia spp. from the southwestern coast of California and Mexico ${ }^{27,28}$, and are also found in the alcyonacean Sinularia polydactyla from Australia ${ }^{29}$.

Our results, combined with previous studies ${ }^{11-14}$, and coupled with the wide distribution of the furanocembranolides, suggest that this class of diterpenoids is responsible for the defenses of diverse octocorals from both tropical and temperate marine communities.

\section{Acknowledgements}

This work was supported by $\mathrm{CNPq}$ and IFS grants. A joint National Science Foundation-CNPq project supported collaborative research in USA and Brazil. We are grateful to Hélène Veervort for assistance with the acquisition of 500 MHz NMR spectra. We acknowledge Kelly Jenkins, Paul Jensen, Prof. Renato C. Pereira and Bernardo P. Gama for their help in performing field experiments. We also thank Dr. Frederick Bayer, National Museum of Natural History Smithsonian Institution, for identification of the gorgonian, and the staff at the Mass Spectrometry Center, University of California-Riverside for providing HRMS. We also thank Dr. Ricardo Coutinho and the IEAPM staff for the use of their facilities in Arraial do Cabo, RJ. LFM thanks CAPES and CNPq for providing a D.Sc. fellowship.

\section{References}

1. Paul, V. J. In Ecological roles of marine natural products; Paul, V. J., Ed.; Comstock Publishing Associates; New York, 1992, p 164.

2. Harvell, C. D.; Fenical, W.; Greene, C. H. Mar. Ecol. Prog. Ser. 1988, 49, 287

3. Hay, M. E.; Satchowicz, J. J.; Cruz-Rivera, E.; Bullard, S.; Deal, M. S.; Lindquist, N. In Methods in chemical ecology, Bioassays methods; Haynes, K. F. and Millar, J. G., Ed.; Chapman and Hall; New York, 1998, p 39.

4. Gerhart, D. J. Mar. Ecol. Prog. Ser. 1984, 19, 181.

5. Pawlik, J. R.; Burch, M. T.; Fenical, W. J. Exp. Mar. Biol. Ecol. 1987, 108,55.

6. Pawlik, J. R.; Fenical, W. Mar. Ecol. Prog. Ser. 1989, 87, 183.

7. Fenical W.; Pawlik, J. R. Mar. Ecol. Prog. Ser. 1991, $75,1$.

8. Pawlik J. R.; Fenical, W. Mar. Ecol. Prog. Ser. 1992, 87, 183.

9. Cronin, G.; Hay, M. E.; Fenical W.; Lindquist, N. Mar. Ecol. Prog. Ser. 1995, 119, 177.

10. Harvell, C. D.; Fenical, W. Limnol. Oceanogr. 1989, 34, 382.

11. Wylie, C. R.; Paul, V. J. J. Exp. Mar. Biol. Ecol. 1989, 129, 141.

12. Van Alstyne, K. L.; Wylie, C. R.; Paul, V. J. J. Exp. Mar. Biol. Ecol. 1994, 178, 17.

13. Gerhart, D. J.; Coll, J. C. J. Chem. Ecol. 1993, 19, 2697.

14. Epifanio, R. de A.; Martins, D. L.; Villaça, R.; Gabriel, R. J. Chem. Ecol. 1999, 25, 2255.

15. Maia, L. F.; Epifanio, R. de A.; Eve, T.; Fenical, W. J. Nat. Prod. 1999, 62, 1322.

16. Epifanio, R. de A.; Gabriel, R.; Martins, D. L.; Muricy, G. J. Chem. Ecol. 1999, 25, 2247.

17. Pereira, R. C.; Yoneshigue-Valentin, Y. Bot. Mar.1999, $42,441$.

18. Pereira, R. C.; Donato, R.; Teixeira, V. L.; Cavalcanti, D. N. Rev. Bras. Biol. 2000, 60, 405.

19. Pereira, R. C. Cavalcanti, D.; Teixeira, V. L. Mar. Ecol. Prog. Ser. 2000, 205, 101.

20. Pereira, R. C.; Pinheiro, M. D.; Gama, B. A. P. Rev. Bras. Biol. (in press).

21. Martins, D. L.; Epifanio, R. de A. J. Braz. Chem. Soc. 1998, 9, 586. 
22. Epifanio, R. de A.; Maia, L. F.; Pinto, A. C.; Hardt, I.; Fenical, W. J. Braz. Chem. Soc. 1998, 9, 187.

23. Vervoort, H.; Fenical, W.; Epifanio, R. de A. J. Org. Chem. 2000, 65, 782.

24. Maia, L. F.; Epifanio, R. de A.; Pinto, A. C. Bol. Soc. Chil. Quím. 1998, 43, 39.

25. Maia, L. F.; Epifanio, R. de A.; Fenical, W. J. Nat. Prod. 2000 (in press).

26. Castro, C. B. Ph. D. Thesis, Universidade de São Paulo, 1990.

27. Fenical, W.; Okuda, R. K.; Bandurraga, M. M.; Culver, P.; Jacobs, R. S. Science 1981, 212, 1512.

28. Bandurraga, M. M. Ph.D. Thesis, University of California, 1982.

29. Bowden, B. F.; Coll, J. C.; Wright, A. D. Aust. J. Chem. 1989, 42, 757.

30. Nunam, G. W. Ph. D. Thesis, University of Newcastle upon Tyne, 1992.
31. Zar, J. H. In Biostatistical analysis; $2^{\text {nd }}$ Ed., PrenticeHall; New Jersey, 1984.

32. Abramson, S. N.; Trischman, J. A.; Tapiolas, D. M.; Harold, E. E.; Fenical, W.; Taylor, P. J. Med. Chem. 1991, 34, 1798.

33. Wright, A. E.; Burres, N. S.; Schulte, G. K. Tetrahedron Lett. 1989, 30, 3491.

34. Missakian, M. G.; Burreson, B. J.; Scheuer, P. J. Tetrahedron 1975, 31, 2513.

35. Ksebati, M. B.; Ciereszko, L. S.; Schmitz, F. J. J. Nat. Prod. 1984, 47, 1009.

36. Williams, D. E.; Andersen, R. J.; Kingston, J. F.; Fallis, A. G. Can. J. Chem. 1987, 66, 2928.

37. Chan, W. R.; Tinto, W. F.; Laydoo, R. S.; Manchand, P. S.; Reynolds, W. F.; McLean, S. J. Org. Chem. 1991, 56, 1773.

38. Reddy, M. V. R.; Lakshman, S.; Rao, A. V. R.; Venkateswarlu, Y.; Rao, J. V. J. Nat. Prod. 1993, 56, 970.

Received: July 24, 2000. 